\title{
Penerapan Strategi Diskriminasi Harga Pada Produk Agrikultur (Studi Kasus Pada Penjual Tanaman Hias di Dusun Dukuh, Desa Kopeng, Kec. Getasan, Kab. Semarang)
}

\author{
Hana Febri Wahyuningtyas ${ }^{1}$ Eristia Lidia Paramita ${ }^{2}$ \\ Universitas Kristen Satya Wacana, Salatiga \\ Email: hanafbr@gmail.com ${ }^{1}$ \\ eristia.paramita@uksw.edu²
}

\begin{abstract}
Abstrak. Penelitian ini bertujuan untuk mendeskripsikan penerapan strategi diskriminasi harga yang dilakukan penjual tanaman hias di Dusun Dukuh, Desa Kopeng, Kecamatan Getasan, Kabupaten Semarang. Metode penelitian yang digunakan adalah metode deskriptif dengan pendekatan kualitatif dan teknik analisis yang digunakan adalah content analysis dan triangulasi sumber. Terdapat lima narasumber kunci dalam penelitian ini, yang semuanya merupakan penjual tanaman hias di Dukuh, Kopeng. Hasil penelitian ini menunjukkan bahwa penjual tanaman hias telah menerapkan tiga tingkatan diskriminasi harga, yaitu dikriminasi harga tingkat satu, diskriminasi harga tingkat dua, diskriminasi harga tingkat tiga, namun terdapat satu tahapan diskriminasi harga yang belum dilakukan, yaitu membagi target market kedalam segmen yang lebih kecil. Meskipun terdapat tahapan yang belum dilakukan penjual, strategi diskriminasi harga ini tetap berjalan baik dan masih terus berdampak pada keuntungan ekonomis hingga sekarang.
\end{abstract}

Kata Kunci: Diskirminasi Harga, Tingakatan Diskriminasi Harga, Tahapan Diskriminasi Harga, Tanaman Hias.

Abstract. This study aims to describe the implementation of price discrimination strategies by ornamental plant sellers in Dusun Dukuh, Desa Kopeng, Kecamatan Getasan, Kabupaten Semarang. The research method used was descriptive method with a qualitative approach and the analysis technique used was content analysis and triangulation. There were five key informants in this study. The results of this study indicated that ornamental plant sellers have implemented three levels of price discrimination, namely level one price discrimination, level two price discrimination, level three price discrimination. But there was one stage of price discrimination that has not been done, which divided the target market into smaller segments. Even though there were stages that have not yet been carried out by the seller, this price discrimination strategy have been continued to run well and continues to have an impact on economic benefits to the present.

Keywords: Price Estimation, Price Discrimination Level, Price Discrimination Stage, Ornamental Plants. 


\section{A. PENDAHULUAN}

Harga merupakan kesepakatan nilai antara penjual dan pembeli (Satria, 2017). Harga juga salah satu bagian terpenting dalam bauran pemasaran yang pada umumnya dikenal dengan "4P (Product, Price, Place, dan Promotion)" dimana harga adalah satu-satunya bagian dalam bauran pemasaran yang menghasilkan pendapatan, dan bagian lain hanya menghasilkan biaya (Kotler et al., 2016). Selain itu harga merupakan bagian yang paling fleksibel, dimana dapat disesuaikan berdasarkan spesifikasi pelanggan (Hupperich et al., 2018). Atas dasar tersebut aspek harga merupakan hal yang sangat membahayakan apabila menggunakan strategi penetapan harga yang salah, karena dapat mempengaruhi kelangsungan hidup perusahaan. Maka dari itu menetapkan harga merupakan hal yang sulit untuk menyeimbangkan antara profitabilitas perusahaan, kepuasan pelanggan, dan permintaan (Hustic \& Gregurec, 2015).

Dalam penetapan harga produk, terdapat beberapa strategi, salah satunya adalah strategi diskriminasi harga. Misalnya pada bidang iklan televisi terdapat diskriminasi harga yang tidak berpengaruh pada persaingan pasar (Ricard \& Crichton, 2017). Pada bidang Pendidikan terdapat diskriminasi harga yang didasarakan pada kualitas calon mahasiswa yang mendaftar (Waldfogel, 2015). Pada bidang maskapai penerbangan terdapat diskriminasi harga yang didasarkan pada elastisitas permintaan (Luttmann, 2019). Lalu pada bidang listrik terdapat diskriminasi harga yang didasarkan pada segmen pelanggan (Simshauser, 2018).

Berdasarkan penjelasan diatas dapat disimpulkan bahwa terdapat penelitian mengenai strategi diskriminasi harga pada sektor jasa yang dilakukan oleh Ricard \& Crichton (2017), Waldfogel (2015), Luttmann (2019), Simshauser (2018) akan tetapi masih minim penelitian mengenai strategi diskriminasi harga pada sektor agrikultur. Penulis menemukan penelitian yang menggunakan objek agrikultur tetapi topik yang diteliti tidak fokus pada strategi diskriminasi harga, melainkan mengenai strategi penetapan harga yang mempertimbangkan preferensi peritel dan pelanggan (Chang et al., 2016). Atas hal inilah penulis menggunakan produk agrikultur yaitu tanaman hias sebagai objek penelitian.

Pada umumnya diketahui bahwa tanaman hias merupakan tumbuhan hidup yang cenderung memiliki siklus hidup yang pendek dan rentan untuk rusak (Chang et al., 2016), tetapi penulis menemukan kelompok penjual tanaman hias yang berani melakukan diskriminasi harga pada produk tanaman hias. Oleh karena itu penulis tertarik untuk meneliti mengenai strategi diskriminasi harga yang diterapkan oleh penjual tanaman hias tersebut.

Salah satu daerah yang memiliki produk unggulan tanaman hias adalah di Dusun Dukuh, Desa Kopeng, Kecamatan Getasan, Kabupaten Semarang. Dusun ini merupakan satu-satunya sentra tanaman hias binaan Forum for Economic Development and Employement Promotion (FEDEP) Kabupaten Semarang ("FEDEP - Barenlitbangda Kabupaten Semarang," 2014). Selain itu pada tahun 2004 Dusun ini memperoleh penghargaan dari Menteri Pertanian. Bukan hanya itu, pengurus kelompok tani tanaman hias di daerah tersebut juga mendapat kesempatan bertemu dengan Bapak Bambang Susilo Yudhoyono yang menjabat Presiden pada waktu tersebut.

Ketika berkunjung di Dusun Dukuh, maka dapat ditemui berbagai macam tanaman hias dengan harga yang relatif murah, yaitu sekitar Rp 3.000 - Rp 500.000, hal ini terjadi karena adanya persaingan harga tiap penjual dan belum adanya patokan harga yang tepat, sehingga setiap penjual tanaman hias memiliki harga yang beragam. Biasanya untuk dapat meningkatkan laba, maka para penjual tanaman hias melakukan diskriminasi harga produk, salah satunya diskriminasi harga berdasarkan pelanggan. Dimana pelanggan yang berbeda, membayar harga yang berbeda untuk produk yang sama (Sugiarto, 2016). Para penjual akan memberikan penawaran harga tinggi kepada para konsumen yang mereka anggap kalangan dewasa dan sudah bekerja dilihat dari penampilan maupun kendaraan 
yang digunakan. Dengan pemikiran bahwa konsumen tidak memiliki pengetahuan mengenai harga jual tanaman hias pada umumnya dan secara ekonomi konsumen tersebut termasuk kalangan yang berani membayar harga tinggi. Namun yang membahayakan adalah ketika penawaran harga tinggi tersebut menyebabkan penurunan konsumen, apalagi ketika konsumen sensitif terhadap harga (Whitfield \& Duffy, 2013).

Berbeda ketika konsumen merupakan kalangan remaja maupun pemuda yang penjual anggap masih bersekolah dilihat dari penampilannya. Maka para penjual tanaman hias akan menawarkan harga yang lebih rendah, karena asumsinya konsumen yang para penjual tangani secara ekonomi atau financial tidak mampu membayar penawaran harga yang lebih tinggi pada umumnya.

Berdasarkan uraian diatas, terlihat bahwa para penjual tanaman hias sebenarnya tidak mengetahui bagaimana sistematis strategi diskriminasi harga. Penjual hanya memanfaatkan peluang untuk meningkatkan laba ketika selera dan penilaian konsumen terhadap tanaman hias berbeda. Maka penulis ingin mengetahui 1) Mengapa penjual menerapkan strategi diskriminasi harga? 2) Berdasarkan apa saja penerapan strategi diskriminasi harga dilakukan? 3) Bagaimana penjual menerapkan strategi diskriminasi harga? dan, 4) Kapan penjual menerapkan strategi diskriminasi harga?

Setelah itu penulis memiliki tujuan untuk mendiskripsikan dan memahami penerapan strategi diskriminasi harga yang dilakukan penjual tanaman hias di Dusun Dukuh. Selain itu, dengan didapatkannya hasil penelitian ini, diharapkan para penjual tanaman hias mampu menerapkan strategi diskriminasi harga dengan baik, sehingga dapat berdampak pada bertambahnya keuntungan yang didapatkan.

\section{B. KAJIAN LITERATUR \\ Strategi Penetapan Harga}

Supaya pemasaran dalam suatu produk maupun jasa dapat sukses, maka setiap perusahaan harus menetapkan harganya dengan tepat (Saragih, 2015). Melalui faktor penetapan harga suatu produk, maka akan terlihat kedudukan kelayakan produk tersebut dari sisi ekonominya (Kencana, 2019).

Menurut Sumarwan (2013) terdapat tiga metode dalam menetapkan harga:

a. Cost-plus pricing, merupakan penetapan harga yang di dasarkan pada biaya produksi.

b. Customer-driven pricing, penentuan tingkat harga optimal untuk produk yang didasarkan pada justifikasi konsumen.

c. Share-driven pricing, penentuan tingkat harga dengan memenangkan pangsa pasar, karena dengan hal tersebut maka produsen dapat memperoleh laba maksimal.

\section{Strategi Diskriminasi Harga}

Keputusan untuk menetapkan harga dipengaruhi oleh lingkungan, persaingan yang rumit, dan kekuatan nilai yang dimiliki oleh perusahaan. Untuk membuat persaingan yang semakin rumit, maka perusahaan tidak menetapkan harga tunggal, melainkan rangkaian harga yang mencakup banyak hal dalam lininya (Kotler et al., 2016). Selain itu, waktu keperluan konsumen, kecepatan pembayaran, tingkat layanan, dan dukungan yang konsumen butuhkan dapat mendorong adanya perbedaan biaya yang signifikan dalam melakukan pelayanan pada para konsumen. Ketika semua itu dilayani dengan satu harga, maka akan terjadi pengorbanan laba yang cukup besar (Nagle \& Muller, 2018).

Atas dasar tersebut maka diperlukan strategi diskriminasi harga. Diskriminasi harga adalah strategi penetapan harga dimana terdapat harga yang berbeda pada produk yang sama tetapi tidak didasarkan pada perbedaan biayanya. Diskriminasi harga menggambarkan strategi pemasaran dalam menetapkan harga produk berdasarkan atribut 
pelanggan atau pasar, seperti perilaku, lokasi, dan status ekonomi (Sugiarto, 2016). Strategi diskriminasi harga dapat menguntungkan konsumen maupun penjual yang mengarah pada kesejahteraan konsumen dan produsen. Selain itu strategi ini dapat membantu penjual mendapatkan kembali biaya tetapnya tanpa meninggalkan banyak pelanggan potensial yang tidak terlayani (Poort \& Borgesius, 2019).

Dalam strategi diskriminasi harga terdapat tiga tingkatan (Poort \& Borgesius, 2019):

a. Diskriminasi harga tingkat pertama, mengacu pada situasi dimana setiap konsumen dikenakan harga individual yang setara dengan kesediaan maksimunnya untuk membayar, dalam tingkatan ini memungkinkan penjual untuk mengambil semua surplus konsumen.

b. Diskriminasi harga tingkat kedua, mengacu pada skema penetapan harga dimana harga suatu barang atau jasa bergantung pada kuantitas pembelian konsumen.

c. Diskriminasi harga tingkat ketiga, penjual menetapkan harga berbeda antara kelompok atau jenis konsumen, seperti berdasarkan harga segmen pelanggan, harga saluran, harga lokasi, dan harga waktu.

Selain itu, sebelum menerapkan strategi diskriminasi harga di perlukan tiga syarat yang harus dipenuhi agar realisasi dari strategi ini dapat berjalan dengan baik (Poort \& Borgesius, 2019).

a. Penjual harus dapat membedakan antar pelanggan atau dapat melakukan segmen pelanggan yang sesuai.

b. Penjual harus memiliki kekuatan pasar yang cukup.

c. Untuk dijual kembali maka harga tidak boleh mahal dan penjual dilarang untuk mencegah arbitrase antar pelanggan.

Berbeda dengan syarat yang dipaparkan oleh Poort \& Borgesius (2019), Sugiarto (2016) menyatakan 3 syarat yang harus dipenuhi sebelum menerapkan diskriminasi harga adalah :

a. Penjual harus memiliki keahlian dan mampu mengendalikan harga.

b. Sifat permintaan dan elastisitas permintaan harus berbeda.

c. Penjual harus mampu melakukan segmentasi pasar.

Setelah syarat-syarat terpenuhi maka selanjutnya tahapan-tahapan untuk melakukan diskriminasi harga dengan baik diperlukan. (Yelkur \& Nêveda Dacosta, 2001) menyatakan terdapat 5 tahapan dalam menerapkan strategi diskriminasi harga:

1. Menyeleksi target market, dimana penjual perlu membagi luasnya target market kedalam segmen yang lebih kecil.

2. Membagi target market menjadi segmen-segmen layanan pelanggan yang lebih kecil.

3. Mentaksirkan permintaan untuk setiap segmen pelanggan.

4. Menentukan reservation price (yang menunjukkan kemampuan membayar masingmasing segmen pelanggan).

5. Langkah terakhir, menetapkan harga untuk masing-masing segmen palanggan.

\section{Persepsi Konsumen Mengenai Harga}

Persepsi merupakan suatu proses yang digunakan oleh individu untuk menyeleksi, menyusun, dan menafsirkan petunjuk informasi untuk menghasilkan gambaran yang mempunyai arti (Kotler et al., 2016). Sedangkan persepsi harga merupakan perasaan konsumen apakah harga suatu produk mahal atau murah (Suhaily \& Darmoyo, 2017). Selain itu, prioritas pemasaran yang terpenting menyangkut harga adalah, bagaimana konsumen sampai pada persepsi harga tersebut. Maka terdapat tiga kunci mengenai persepsi harga, yaitu harga referensi, asumsi harga kualitas, dan akhiran harga (Samosir \& Prayoga, 2015). Tiga kunci tersebut yang akan menjadi dasar penelitian mengenai persepsi harga. 


\section{METODOLOGI PENELITIAN}

Penelitian ini menggunakan metode deskriptif dengan pendekatan kualitatif. Ini berarti konsep cara pengerjaan penelitian bersifat natural, dengan melakukan pendekatan khusus, dan menggunakan penilaian yang terkonsep yaitu dengan cara menggambarkan secara jelas keadaan di lapangan yang nantinya akan menjadi pusat pemikiran peneliti (Sekaran \& Bougie, 2016). Oleh karena itu, penelitian ini memaparkan fakta sebenarnya sama seperti keadaan yang didapati di lapangan ketika penelitian ini berlangsung.

Lalu sebelum menentukan populasi maupun sampel pada penelitian ini. Penulis terlebih dahulu menetapkan satuan analisis dan satuan pengamatan agar tercapainya seluruh informasi yang diperlukan.

Satuan analisis dalam penelitian ini merupakan penjual tanaman hias yang memiliki karakteristik dan kualifikasi sebagai berikut:

1. Penjual tanaman hias merupakan penduduk asli Dusun Dukuh, Desa Kopeng, Kecamatan Getasan, Kabupaten Semarang.

2. Berjualan di area Dusun Dukuh, Desa Kopeng, Kecamatan Getasan, Kabupaten Semarang.

3. Usaha tanaman hias merupakan usaha milik sendiri.

Satuan pengamatan dalam penelitian ini sama dengan satuan analisis yaitu penjual tanaman hias, tetapi memiliki tambahan karakteristik dan kualifikasi sebagai berikut:

1. Penjual tanaman hias merupakan penduduk asli Dusun Dukuh, Desa Kopeng, Kecamatan Getasan, Kabupaten Semarang.

2. Berjualan di area Dusun Dukuh, Desa Kopeng, Kecamatan Getasan, Kabupaten Semarang.

3. Usaha tanaman hias merupakan usaha milik sendiri

4. Penjual tanaman hias sudah berjualan lebih dari 10 tahun

5. Usaha tanaman hias yang dimiliki sudah besar dimana tempat usaha tanaman hias memiliki luas kurang lebih 500-3000 meter dan sudah memiliki tenaga kerja kurang lebih lima tenaga kerja.

6. Usaha tanaman hias yang dimiliki merupakan usaha yang cukup besar atau tergolong sedang, dimana luas area tempat usaha yang digunakan 20-200 meter dan belum memiliki tenaga kerja.

7. Usaha tanaman hias yang dimiliki merupakan usaha yang cenderung masih kecil dimana luas area tempat usaha yang digunakan kurang lebih 3-10 meter dan belum memiliki tenaga kerja.

Selain itu setelah melakukan survei dan wawancara, didapati bahwa terdapat populasi yaitu 71 penjual tanaman hias di Dusun Dukuh, Desa Kopeng, Kecamatan Getasan, Kabupaten Semarang.

Maka dari hasil tersebut penulis menggunakan 5 sampel yang memuat karakteristik dan kualifikasi dari satuan analisis dan satuan pengamatan pada penelitian ini, yaitu 2 narasumber yang memiliki usaha tanaman hias cukup besar/ sedang, 2 narasumber yang memiliki usaha tanaman hias terbesar di daerah tersebut, dan 1 narasumber yang memiliki usaha tanaman hias yang cenderung masih kecil.

Sedangkan teknik pengambilan sampel yang diterapkan pada penelitian ini menggunakan teknik purposive sampling dimana pengambilan sampel didasarkan pada karakteristik dan kualifikasi yang dibutuhkan peneliti.

Teknik pengumpulan data yang akan digunakan adalah teknik observasi, teknik wawancara/ interview, dan dokumentasi.

a) Teknik observasi ini akan digunakan untuk mengetahui secara langsung bagaimana para penjual berinteraksi dengan konsumen yang berbeda dan bagaimana cara mereka menentukan harga pada tiap konsumen. 
b) Teknik wawancara yang mendalam akan digunakan untuk mengumpulkan informasi dan data seputar diskriminasi harga yang dilakukan para penjual tanaman hias dan rencananya ketika kegiatan wawancara ini berlangsung akan direkam agar menjadi bukti bahwa informasi dan data yang dikumpulkan dapat dipercaya.

c) Teknik dokumentasi ini bermanfaat untuk melengkapi data-data yang didapat dari hasil wawancara dan observasi.

Dalam penelitian kualitatif terdapat tiga langkah penting dalam menganalisis data, yaitu (Sekaran \& Bougie, 2016):

a. Reduksi data, dimana semua data yang sudah didapatkan disaring, difokuskan, dan disusun secara sistematis sehingga mudah dipahami.

b. Penyajian data, usaha untuk mengumpulkan data yang sudah disaring secara jelas dalam bentuk grafik, tabel, gambar dan lain sebagainya.

c. Kesimpulan, tercapainya jawaban dari persoalan penelitian, sehingga pada akhirnya diperoleh tujuan dan manfaat dari penelitian tersebut.

selain itu, atas dasar pentingnya data dalam suatu penelitian maka diperlukan teknik pengujian agar data yang diperoleh benar dan dapat dipercaya. Maka peneliti menggunakan teknik uji kebenaran menggunakan triangulasi sumber, dimana penulis membandingkan data yang diperoleh dari wawancara dengan data yang diperoleh dari observasi dan wawancara dengan konsumen.

\section{HASIL DAN PEMBAHASAN}

\section{Karakteristik Narasumber}

Dalam rangka memperoleh data dalam penelitian ini maka penulis melakukan kunjungan pertama pada tanggal 30 Januari 2020 untuk mencari informasi mengenai penjual dan keadaan di lapangan, hingga pada tanggal 28 Februari 2020 penulis mendapatkan data yang diperlukan dari 5 narasumber sebagai informan. Profil dari kelima narasumber yang dijadikan informan kunci disajikan pada Tabel 1.

Tabel 1

Karakteristik Narasumber

\begin{tabular}{|c|c|c|c|c|c|}
\hline \multicolumn{6}{|c|}{ narakteristik ivarasumoer } \\
\hline \multirow[t]{2}{*}{ Informasi } & \multicolumn{5}{|c|}{ Narasumber } \\
\hline & A & B & C & D & $\mathbf{E}$ \\
\hline $\begin{array}{l}\text { Tempat, } \quad \text { Tanggal } \\
\text { lahir narasumber }\end{array}$ & $\begin{array}{l}\text { Kab. Semarang } \\
14 \text { Agustus } \\
1956\end{array}$ & $\begin{array}{l}\text { Kab. Semarang } \\
15 \text { Agustus } \\
1966\end{array}$ & $\begin{array}{l}\text { Kab. } \\
\text { Semarang } 16 \\
\text { November } \\
1996\end{array}$ & $\begin{array}{l}\text { Kab. Semarang } \\
1952\end{array}$ & $\begin{array}{l}\text { Kab. } \\
\text { Semarang } \\
1950\end{array}$ \\
\hline Alamat narasumber & $\begin{array}{l}\text { Dukuh, Kopeng } \\
\text { RT 06, RW } 08\end{array}$ & $\begin{array}{l}\text { Dukuh, Kopeng } \\
\text { RT 02, RW } 08\end{array}$ & $\begin{array}{l}\text { Dukuh, } \\
\text { Kopeng RT 02, } \\
\text { RW } 08\end{array}$ & $\begin{array}{l}\text { Dukuh, Kopeng } \\
\text { RT 02, RW } 08\end{array}$ & $\begin{array}{l}\text { Dukuh, } \\
\text { Kopeng RT } \\
\text { 05, RW } 08\end{array}$ \\
\hline $\begin{array}{l}\text { Luas kios tanaman } \\
\text { hias yang dimiliki } \\
\text { narasumber }\end{array}$ & $4 \times 17$ meter & $20 \times 8$ meter & $\begin{array}{l}200 \text { meter } \\
\text { persegi }\end{array}$ & $\begin{array}{l}3000 \text { meter } \\
\text { persegi }\end{array}$ & $\begin{array}{l}600 \text { meter } \\
\text { persegi }\end{array}$ \\
\hline $\begin{array}{l}\text { Lama berjualan } \\
\text { tanaman hias }\end{array}$ & 18 tahun & 30 tahun & 24 tahun & 30 tahun & 30 tahun \\
\hline Jumlah tenaga kerja & - & - & - & 22 & 2 \\
\hline Kepemilikan usaha & $\begin{array}{l}\text { Usaha milik } \\
\text { sendiri }\end{array}$ & $\begin{array}{l}\text { Usaha milik } \\
\text { sendiri }\end{array}$ & $\begin{array}{l}\text { Usaha milik } \\
\text { sendiri }\end{array}$ & $\begin{array}{l}\text { Usaha milik } \\
\text { sendiri }\end{array}$ & $\begin{array}{l}\text { Usaha milik } \\
\text { sendiri }\end{array}$ \\
\hline $\begin{array}{l}\text { Alamat kios tanaman } \\
\text { hias }\end{array}$ & $\begin{array}{l}\text { Kab. Semarang } \\
14 \text { Agustus } \\
1956\end{array}$ & $\begin{array}{l}\text { Kab. Semarang } \\
15 \text { Agustus } \\
1966\end{array}$ & $\begin{array}{l}\text { Kab. } \\
\text { Semarang } 16 \\
\text { November } \\
1996\end{array}$ & $\begin{array}{l}\text { Kab. Semarang } \\
1952\end{array}$ & $\begin{array}{l}\text { Kab. } \\
\text { Semarang } \\
1950\end{array}$ \\
\hline $\begin{array}{l}\text { Jumlah jenis produk } \\
\text { tanaman hias yang } \\
\text { dijual }\end{array}$ & $>100$ & $>200$ & $>100$ & $100-500$ & $>200$ \\
\hline
\end{tabular}


Dari hasil diatas, didapati bahwa seluruh narasumber yang dijadikan informan kunci merupakan penduduk asli Dusun Dukuh, Desa Kopeng dan kios tanaman hias yang dimiliki oleh setiap narasumber juga berada pada area Dusun Dukuh, Desa Kopeng. Namun, terdapat beberapa karakteristik yang berbeda seperti luas kios dan lamanya pengalaman, sehingga diduga faktor tersebut menyebabkan beberapa perbedaan dalam menerapkan strategi diskriminasi harga yang dilakukan oleh narasumber.

Maka penulis akan menjabarkan didalam 4 persoalan penelitian apakah beberapa karakteristik yang berbeda tersebut mempengaruhi cara setiap narasumber menerapkan diskriminasi harga. Setiap persoalan penelitian dijabarkan berdasarkan hasil wawancara mendalam dengan narasumber dan observasi yang dideskripsikan menggunakan teori yang sudah ditentukan.

\section{Alasan Penjual Tanaman Hias Menerapkan Strategi Diskriminasi Harga}

Menurut informasi yang diperoleh dilapangan, terdapat 3 alasan penjual tanaman hias menerapkan strategi diskriminasi harga:

\section{Cost-Plus Pricing}

Pada awalnya para penjual tanaman hias menentukan harga yang didasarkan pada biaya produksi tanaman hias, yang berarti penjual tanaman hias menggunakan strategi penetapan harga Cost-Plus Pricing (Sumarwan, 2013). Harga dasar ini merupakan harga dengan tingkat laba yang rendah, karena para penjual tidak mempertimbangkan faktor lain seperti keindahan tanaman, kuantitas pembelian, waktu tanam tanaman hias dan lain sebagainya.

\section{Faktor internal penjual}

Faktor internal yang dimaksud yaitu penjual tanaman hias mengeluhkan rendahnya keuntungan yang didapatkan, terlebih lagi tidak adanya patokan harga yang mengatur harga-harga tanaman hias didaerah tersebut, sehingga rentan terjadi persaingan harga yang membuat harga tanaman hias sangat rendah. Ketika penulis mendatangi narasumber E untuk yang kedua kalinya, beliau sedang kesal dikarenakan konsumen tetapnya, yaitu konsumen peritel berpindah ke kios tanaman hias lain, hal ini yang disebabkan karena harga yang ditawarkan di kios tersebut lebih rendah. Sejalan dengan pernyataan narasumber $\mathrm{E}$, narasumber $\mathrm{B}$ juga mengeluhkan hal yang sama.

Narasumber E: "masyarakat sini pada ngajak miskin, harga pot sama kawat saja pada naik kok harga kembang turun terus, mau ambil untung darimana" (pernyataan narasumber E tanggal 31 Januari 2020)

Narasumber B: "yang berdampak buruk karena pembedaan harga ini ya usaha sekitar, kalo konsumen sudah menemukan harga terendah di kios tertentu ya mereka langsung beli disitu terus, ini khusus buat konsumen bakul (peritel) ya. Memang buruknya disini seperti itu, para penjual berebut konsumen bakul (peritel) dengan berlomba memberikan harga termurah, padahal untungnya saja sudah mepet" (Hasil wawancara dengan narasumber B tanggal 01 Februari 2020)

Dari pernyataan tersebut maka terlihat bahwa para penjual tanaman hias juga mengandalkan penerapan strategi diskriminasi harga untuk lebih menaikkan laba, karena jika hanya terus mengandalkan harga dasar maka tidak akan maju dan tidak menutup kemungkinan harga akan terus sulit untuk naik karena adanya persaingan harga pada usaha sekitar. 


\section{Opportunity Profit}

Opportunity Profit yang dimaksud adalah peluang untuk mendapatkan laba yang lebih tinggi dengan memanfaatkan persepsi konsumen dan kesedian maksimum konsumen untuk membayar.

"pada awalnya karena ada konsumen yang sepertinya pendatang, dilihat dari penampilannya orang mampu datang untuk mencari tanaman hias lalu saya mencoba menawarkan dengan harga tinggi, konsumen itu langsung mau. Jadi saya coba melakukan hal yang sama ketika saya tahu bahwa itu merupakan konsumen tamu (konsumen umum yang bukan peritel)" (hasil wawancara dengan responden A tanggal 22 Februari 2020)

Oleh karena itu para penjual tanaman hias mulai memanfaatkan peluang yang ada dengan menetapkan harga yang berbeda untuk setiap konsumennya.

"jika cuma menggunakan harga dasar, untung yang didapat sangat sedikit kisaran Rp500-Rp1000 saja, makanya kami inisiatif untuk memberikan harga yang beda pada tamu (konsumen umum yang bukan peritel), apalagi kalo tamu (konsumen umum yang bukan peritel) itu suka dengan tanaman hias berapapun harga yang ditawarkan kalo dia suka dengan bunga itu ya di bayar. Apalagi tidak setiap hari ada konsumen yang datang, kalo tidak bedakan harga antar konsumen usaha saya tidak maju, makanya lebih baik memanfaatkan peluang yang ada." (Hasil wawancara dengan narasumber B tanggal 31 Januari 2020).

Informasi dari narasumber diatas menjelaskan bahwa pada intinya penjual tanaman hias melakukan diskriminasi harga karena faktor internal yaitu profit yang didapatkan begitu rendah yang disebabkan oleh karena penetapan harga dasar yang rendah dan adanya persaingan harga, lalu terdapat peluang untuk meningkatkan keuntungan dengan menyesuaikan harga berdasarkan konsumen.

Para penjual beranggapan bahwa tiga alasan tersebut kuat untuk dapat menetapkan strategi diskriminasi harga pada tanaman hias, karena dampaknya dapat mensejahterakan penjual maupun pembeli. Maka pernyataan tersebut sejalan dengan penelitian yang dilakukan oleh Simshauser (2018) yaitu strategi diskriminasi harga dapat memberi kesejahteraan pada produsen dan konsumen.

Narasumber A: "ya kalau kita membedakan harga sama pembeli tidak cuma memanfaatkan mereka, tapi kita juga menyeimbangi dengan pelayanan yang baik, selain itu kami memberi informasi mengenai kualitas dan informasi tentang tanaman yang dipilih" (Hasil wawancara dengan narasumber A tanggal 31 Januari 2020).

Narasumber B: "saya berani membedakan harga antar pembeli karena sudah terbiasa, dan sudah punya insting mana yang bakul (peritel), mana yang pembeli tam (konsumen umum yang bukan peritel), mana pembeli yang suka dengan tanaman hias, jadi saya rasa perbedaan harga yang saya lakukan tepat karena belum ada yang protes" (Hasil wawancara dengan narasumber D tanggal 31 Januari 2020).

Selain karena penerapan diskriminasi harga ini dapat berdampak baik untuk konsumen maupun penjual, pengalaman penjual dalam menerapkan diskriminasi hargapun sudah lama yaitu mayoritas 30 tahun, sehingga penjual sudah memiliki bekal pengalaman dan keahlian, maka hal tersebut sudah memenuhi salah satu syarat yang harus dipenuhi dalam melakukan diskriminasi harga yang dipaparkan oleh Sugiarto (2016) yaitu penjual harus sudah memiliki keahlian untuk membedakan antar pelanggan dan melakukan segmentasi pasar.

Alasan-alasan yang sudah dijabarkan diatas mayoritas merupakan jawaban dari narasumber yang memiliki kios cenderung masih kecil hingga sedang, yaitu narasumber $A, B, C$, yang notabennya narasumber tersebut tidak memiliki jumlah tanaman hias dan pelanggan sebanyak narasumber yang memiliki kios besar, sehingga apabila tidak menerapkan diskriminasi harga setiap harinya laba yang narasumber $A, B$, dan $C$ dapatkan 
sangat rendah dan sulit untuk lebih meningkatkan usaha tanaman hias yang narasumber miliki.

\section{Dasar Ditetapkannya Diskriminasi Harga}

Diskriminasi harga memiliki tiga tingkatan yang menjadi dasar, yaitu diskriminasi harga tingkat pertama yang didasarkan pada individu konsumen, tingkat kedua yang didasarkan pada kuantitas pembelian, dan tingkat ketiga yang didasarkan pada kelompok konsumen (Poort \& Borgesius, 2019).

Maka setelah penulis melakukan penelitian pada penjual tanaman hias di Dusun Dukuh didapati bahwa para penjual tanaman hias yang menjadi narasumber mayoritas menerapkan tiga tingkatan diskriminasi harga yang dijelaskan secara singkat dalam Bagan 1.

\section{Bagan 1}

\begin{tabular}{|c|} 
Diskriminasi Tingkat Pertama, menetapkan harga yang berbeda untuk \\
setiap individu konsumen tamu.
\end{tabular}

Diskriminasi Tingkat Ketiga, Penjual menerapkan harga yang berbeda pada kelompok konsumen peritel dan konsumen tamu.

Tingkatan Diskriminasi Harga yang Dilakukan Penjual Tanaman Hias Sumber: Data Primer (2020) yang diolah

Dari lima narasumber yang menjadi informan kunci, hanya ada satu narasumber yang tidak menerapkan diskriminasi harga tingkat pertama dan kedua. Atas hal tersebut maka penulis menguraikan tiga dasar ditetapkannya strategi diskriminasi harga yang dilakukan penjual di Dusun Dukuh sebagai berikut:

\section{a. Diskriminasi Tingkat Pertama}

Pada tingkatan ini para penjual menerapkan diskriminasi harga di dasarkan pada setiap individu konsumen. Ketika penulis mewawancarai responden $\mathrm{C}$ dan responden $\mathrm{D}$ didapati pernyataan secara jelas bahwa para penjual menerapkan harga yang berbeda untuk setiap individu konsumen.

Responden C : "harga itu tergantung siapa yang beli, kalo keliatan orangnya mampu ya saya kasih harga tinggi, tapi kalo orangnya kok kira-kira tidak meyakinkan ya saya kasih harga yang tidak tinggi yang penting saya sudah dapat untung sudah cukup buat saya. Jenis orang beli itu keliatan dari gelagat-gelagatnya" (Hasil Wawancara narasumber C saat wawancara tanggal 31 Januari 2020).

Responden D : "kalau yang beli tamu pakai mobil mewah, wajah Chinese harga yang ditawarkan bisa tinggi, seperti ini tadi bunga petunia yang harganya hanya Rp.50.000 saya tawarkan kepada pembeli yang berwajah Chinese seharga Rp100.000 langsung dibayar tanpa negosiasi. Tetapi, berbeda jika yang beli anak kecil, masih sekolah, mereka saja masih minta uang orang tua tidak mungkin saya tawarkan dengan harga tinggi" (Pernyataan narasumber D saat wawancara tanggal 01 Februari 2020).

Dari pernyataan tersebut dapat dijelaskan bahwa penjual tanaman hias sedang menerapkan diskriminasi harga tingkat pertama, yaitu penjual menerapkan harga yang berbeda pada setiap individu konsumen berdasarkan kesediaan maksimum konsumen untuk membayar (Poort \& Borgesius, 2019). Dapat terlihat bahwa setiap individu konsumen 
tamu ${ }^{1}$ dikenakan harga yang berbeda-beda tanpa ada patokan maksimal maupun minimal yang jelas.

\section{b. Diskirminasi Harga Tingkat Kedua}

Bukan hanya berdasarkan konsumen saja, penjual tanaman hias juga memberikan harga yang berbeda kepada konsumen yang membeli dalam jumlah besar, yaitu dengan memberikan potongan harga maupun bonus. Pada tingkatan ini semua narasumber menerapkannya, namun yang paling sering menerapkan tingkatan ini adalah narasumber A, karena mayoritas konsumen narasumber A merupakan konsumen tamu, jarang terdapat konsumen peritel yang datang.

"jika ada yang beli banyak ya harganya beda lagi, tapi ini khusus konsumen tamu (konsumen umum yang bukan peritel) ya, kalau yang beli konsumen peritel saya tidak membedakan harga, karena untung yang didapat jika jual ke konsumen peritel sudah mepet, paling saya kasih bonus satu atau dua tanaman hias jika memang belinya banyak" (Hasil wawancara dengan narasumber A saat wawancara tanggal 01 Februari 2020).

Dari pernyataan tersebut maka dapat diketahui bahwa potongan harga ini jarang ditetapkan pada konsumen peritel karena untuk segmen peritel harga sudah terdapat patokan sendiri sehingga keuntungan yang didapatkan tidak banyak dan memberikan potongan harga untuk segmen peritel tidak efektif.

Pada penelitian Simshauser (2018) juga terdapat penerapan diskriminasi harga tingkat kedua dan dijelaskan bahwa para pelaku diskriminasi harga tingkat kedua harus berhatihati apabila tidak ada batasan jumlah kuantitas yang ditentukan maka konsumen akan menjadikan diskon sebagai penawaran tetap. Maka alangkah lebih baik para penjual juga memberikan batasan dan perhitungan secara baik agar konsumen tidak memanfaatkan kuantitas pembeliannya untuk terus meminta potongan harga yang pada akhirnya berdampak pada berkurangnya laba yang didapatkan.

\section{c. Diskriminasi Harga Tingkat Ketiga}

Selain itu setelah dilakukan analisis berdasarkan pernyataan penjual dengan teori yang ada terdapat hasil bahwa para penjual tanaman hias juga menerapkan diskriminasi harga tingkat ketiga, dimana penjual tanaman hias menentukan 2 kelompok konsumen yang dikenai harga berbeda, yaitu konsumen peritel dan konsumen tamu, seperti yang disampaikan dalam kutipan wawancara berikut ini.

"kalau yang beli kelompok bakul ya saya kasih harga bakul, tapi kalau yang beli tamu ya saya kasih harga tamu" (Pernyataan narasumber A saat wawancara tanggal 03 Februari 2020).

Dengan pernyataan tersebut terlihat jelas bahwa penjual menjadikan dua segmen konsumen tersebut sebagai kelompok utama untuk ditetapkan harga yang berbeda.

Dari semua tingakatan diskriminasi harga yang sudah dipaparkan diatas, terdapat satu narasumber yang jarang menerapkan diskriminasi harga tingkat pertama dan kedua yaitu narasumber $\mathrm{E}$ dikarenakan lokasi kios yang dimiliki narasumber $\mathrm{E}$ tidak strategis sehingga jarang ada konsumen tamu, maka walaupun lokasi kios yang dimiliki tergolong kios yang besar, namun tidak strategis mempengaruhi jenis konsumen yang datang.

Berbeda dengan kios yang dimiliki narasumber $\mathrm{D}$, beliau memiliki kios yang besar, lokasi strategis, dan penataan yang baik, sehingga banyak konsumen dengan berbagai jenis yang datang, dan itu juga mempengaruhi lancarnya penerapan diskriminasi harga yang dilakukan. Hal tersebut sejalan dengan penelitian Luttmann (2019), bahwa kekuatan pasar mempengaruhi kelancaran penerapan diskriminasi harga.

\footnotetext{
${ }^{1}$ Kata yang digunakan penjual tanaman hias di Dusun Dukuh untuk menyebutkan konsumen yang bukan peritel (konsumen umum), seperti wisatawan, pengoleksi tanaman hias, pelajar dan lain-lain.
} 
Selain berdasarkan tiga dasar yang sudah dijabarkan diatas, dari hasil wawancara penulis mendapati bahwa para penjual tanaman hias juga melakukan perbedaan harga berdasarkan bentuk, yaitu para penjual, menjual tanaman hias dengan jenis yang sama, ukuran yang sama, dalam pot yang sama tetapi memiliki harga yang berbeda karena keindahan dan kualitas tanaman hias yang dihasilkan berbeda.

Perbedaan harga berdasarkan bentuk tersebut sejalan dengan teori yang dipaparkan oleh Kotler et al., (2016) mengenai strategi penetapan harga berdasarkan bentuk produk, yaitu penetapan harga yang berbeda pada produk yang berbeda namun perbedaan harga tersebut tidak berdasarkan pada biaya yang dikeluarkan. Akan tetapi harga berdasarkan bentuk produk ini bukan bagian dari diskriminasi harga, karena Griffiths \& Wall (2005) menyatakan bahwa tidak termasuk diskriminasi harga apabila perbedaan harga tersebut didasarkan pada kualitas atau layanannya.

Maka dari penjelasan di atas dapat disimpulkan bahwa dasar diterapkannya diskriminasi harga adalah berdasarkan konsumen dan kuantitas pembelian yang diimplikasikan pada tingkatan diskriminasi harga, dimana para penjual tanaman hias di Dusun Dukuh menerapkan tingakatan pertama, kedua, dan ketiga diskriminasi harga.

\section{Cara Dan Proses Penjual Menerapkan Diskriminasi Harga}

Setelah penulis melakukan wawancara terkait proses diterapkannya strategidiskriminasi harga didapati tahapan dalam menerapkan diskriminasi harga berdasarkan konsumen yang dijelaskan pada Bagan 2:

\section{Bagan 2}

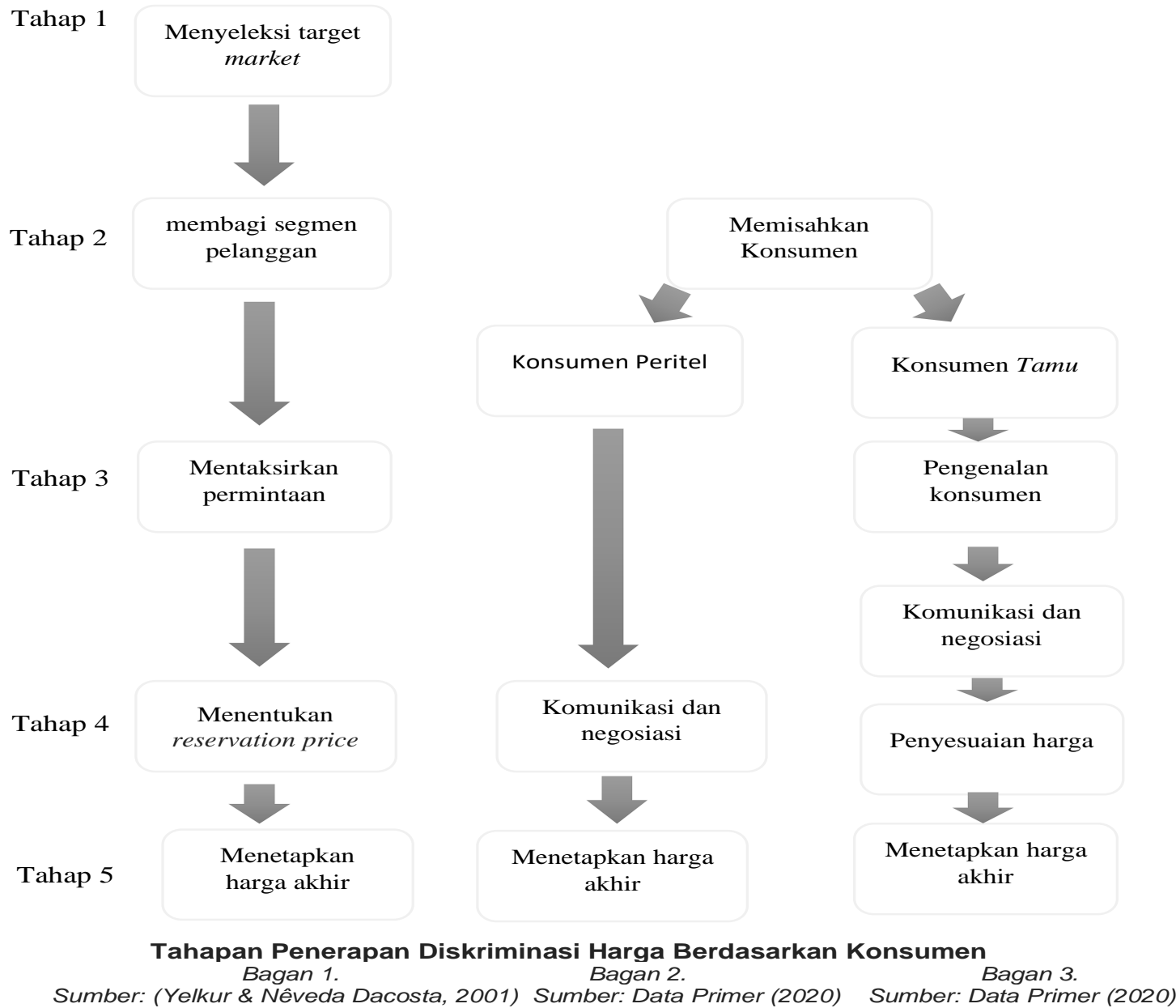


a. Memisahkan segmen konsumen, penjual memisahkan 2 segmen konsumen inti, yaitu segmen konsumen peritel dan segmen konsumen tamu ${ }^{2}$. Dengan cara melihat kendaraan yang digunakan, tetapi biasanya para penjual sudah hafal dengan konsumen peritel karena mereka sudah melakukan pembelian hampir setiap hari. Pada tahap ini sesuai dengan tahap kedua diterapkannya diskriminasi harga yaitu membagi segmen-segmen layanan pelanggan yang lebih kecil (Yelkur \& Nêveda Dacosta, 2001).

b. Pengenalan konsumen secara mendalam, tahap ini dilakukan untuk segmen konsumen tamu karena untuk segmen peritel sendiri para penjual sudah hafal dan mengetahui pola pembelian konsumen peritel. Cara ini juga digunakan untuk mengetahui kesediaan maksimum konsumen untuk membayar. Untuk melakukan cara ini, yang pertama para penjual melihat dari tampilan dan kendaraan yang digunakan, setelah itu melihat gelagat dan cara konsumen melihat maupun memilih tanaman hias. Pada tahap ini penjual sudah melaksanakan tahapan ketiga, yaitu mentaksirkan permintaan untuk setiap segmen pelanggan (Yelkur \& Nêveda Dacosta, 2001).

c. Komunikasi dan negosiasi berbeda antar konsumen yang dilayani, dalam tahap ini dilakukan dengan cara berbeda khususnya untuk segmen konsumen peritel dan konsumen tamu, dimana jika komunikasi dan negosiasi yang dilakukan untuk segmen peritel biasanya para peritel langsung mengambil tanaman hias yang dipilih, setelah itu dilakukan negosiasi harga, bahkan terkadang tidak perlu negosiasi, karena konsumen peritel sudah hafal dengan harganya, sehingga ketika sudah selesai memilih tanaman langsung tinggal dijumlah harganya. Berbeda dengan konsumen peritel, untuk konsumen tamu para penjual berkomunikasi dengan memberikan informasi-informasi mengenai tanaman hias dan sedikit mencari tahu mengenai konsumen yang dilayani. Untuk negosiasi, sudah pasti harga awal yang ditawarkan cukup tinggi namun apabila konsumen tidak menawar maka harga tinggi itulah yang diberikan. Pada tahap ini penjual sudah melakukan tahapan keempat, yaitu menentukan reservation price (yang menunjukkan kemampuan membayar masing-masing segmen pelanggan) (Yelkur \& Nêveda Dacosta, 2001).

d. Menetapkan harga akhir, tahap paling akhir ini merupakan tahap yang relatif, jika untuk konsumen peritel tahap ini sudah pasti selalu sama, karena tidak akan ada perubahan harga, kecuali ada faktor tertentu untuk adanya kenaikan harga. Namun untuk konsumen tamu, tahap ini merupakan cara yang paling relatif, karena setiap individu konsumen tamu dikenai harga yang berbeda, tidak ada patokan batasan maksimal maupun minimal, sehingga jika konsumen tidak mengerti mengenai harga tanaman hias pada umumnya maka dapat dikenai dengan harga yang cukup tinggi sesuai dengan hasil analisis pengenalan mendalam penjual terhadap konsumen. Tahap ini juga sudah sesuai dengan tahapan akhir yang di paparkan oleh Yelkur \& Nêveda Dacosta (2001) .

Langkah-langkah yang dilakukan penjual untuk menerapkan strategi diskriminasi harga sudah sesuai dengan tahapan yang dilakukan Yelkur \& Nêveda Dacosta (2001), akan tetapi para penjual di Dusun Dukuh tidak melakukan tahapan yang pertama, yaitu menyeleksi target market karena para penjual tidak menetapkan target market dalam penjualan tanaman hias dan kurangnya pengetahuan penjual mengenai ketentuan diskriminasi harga.

\footnotetext{
${ }^{2}$ Kata yang digunakan penjual tanaman hias di Dusun Dukuh untuk menyebutkan konsumen yang bukan peritel (konsumen umum), seperti wisatawan, pengoleksi tanaman hias, pelajar dan lain-lain. 
Selain langkah-langkah tersebut para penjual juga mempunyai cara lain dalam menerapkan diskriminasi harga, yaitu dengan membedakan harga berdasarkan kuantitas pembelian, semakin banyak tanaman hias yang dibeli konsumen maka penjual akan menyesuaikan harga dengan memberikan potongan harga maupun diskon. Cara ini dilakukan bukan berdasarkan karena konsumen peritel biasanya membeli dalam jumlah banyak, tetapi memang ada dasar tersendiri, hal tersebut jelas dinyatakan sebagai berikut: "bukan karena yang beli bakul saya kasih diskon untuk yang beli banyak, karena bakulpun (peritel) tidak selalu membeli banyak, karena banyak pula bakul kecil-kecilan yang membawa kendaraan sepeda motor seperti tukang sayur dan mereka cenderung tidak membeli di satu tempat. Cara ini berlaku untuk semua konsumen, tetapi yang benar-benar kuantitas pembeliannya besar" (Pernyataan narasumber $C$ saat wawancara tanggal 03 Februari 2020).

Penerapan cara dan proses tersebut dinilai baik dan adil oleh penjual, karena cara ini bukan hanya menguntungkan penjual, melainkan konsumen juga akan mendapatkan produk dengan harga dan kualitas yang sesuai. Hal yang menjadi kesulitan dalam menerapkan cara ini adalah apabila konsumen sensitif terhadap harga dan kurangnya pengalaman dalam mengenali konsumen yang dilayani.

Narasumber B: "susahnya ya kalau ada pembeli yang pelit, tidak tahu harga pada umumnya tapi nawar dibawah harga rata-rata" (Pernyataan narasumber B saat wawancara tanggal 21 Februari 2020).

Narasumber A: "pernah saya ditipu konsumen, ngakunya peritel ternyata konsumen tamu" (Pernyataan narasumber A saat wawancara tanggal 21 Februari 2020).

Dari pernyataan tersebut dapat dikatakan bahwa konsumen sensitif terhadap harga. Hal ini dapat terjadi karena persepsi harga tiap konsumen berbeda (Suhaily \& Darmoyo, 2017), dan kurangnya informasi mengenai harga tanaman hias pada umumnya. Selain itu faktor kurangnya pengalaman juga mengakibatkan kesulitan dalam menerapkan diskriminasi harga seperti yang di alami narasumber A yang baru 18 tahun berjualan tanaman hias, karena kurangnya pengalaman dalam mengenali konsumen sehingga masih salah sasaran.

Dari cara dan dasar penerapan diskriminasi harga yang sudah dipaparkan terdapat perbedaan harga yang tidak terlalu tinggi. Penulis membatasi tiga jenis tanaman yang menjadi dasar wawancara ditetapkannya dikriminasi harga yaitu:

Tabel 2

\begin{tabular}{|c|c|c|}
\hline \multicolumn{3}{|c|}{ Perbedaan Harga Tanaman Hias Antar Konsumen } \\
\hline No & Jenis Tanaman & Perbedaan Harga \\
\hline 1. & Kaktus & Rp1000-Rp3000 \\
\hline 2. & Sukulen & Rp1000-Rp3000 \\
\hline 3. & Petunia & Rp2000-Rp3500 \\
\hline
\end{tabular}

Perbedaan harga tanaman hias pada setiap bentuk diskriminasi harga tidak terlalu tinggi, maka sesuai dengan syarat ketiga ditetapkannya diskirminasi harga yang menyatakan harga tidak boleh terlalu mahal (Poort \& Borgesius, 2019).

\section{Waktu Ditetapkannya Strategi Diskriminasi Harga}

Dari hasil wawancara penjual menyatakan bahwa dilakukannya diskriminasi harga adalah ketika terdapat konsumen yang dapat dilakukan penyesuaian harga dan akan terus dilakukan berdasarkan situasi yang ada. Sebenarnya peneliti belum menemukan teori yang membahas mengenai waktu di tetapkannya diskriminasi harga, hanya saja terdapat teori yang memaparkan bahwa strategi diskriminasi harga dapat dilakukan ketika memenuhi syarat (Sugiarto, 2016). Ketika sudah memenuhi syarat maka diskriminasi akan diterapkan pada situasi dan konsumen yang tepat. 
Setelah melakukan wawancara dan observasi penulis dapat menyimpulkan bahwa para penjual sudah memenuhi syarat sesuai yang di paparkan oleh Sugiarto (2016) dan (Poort \& Borgesius, 2019) yaitu:

a) Penjual sudah dapat membedakan segmen pelanggan

b) Penjual sudah memberikan harga yang murah untuk konsumen yang membeli bertujuan dijual kembali.

c) Penjual memiliki kekuatan pasar yang cukup untuk dapat menerapkan diskriminasi harga

Hal ini juga terbukti dari pernyataan salah satu konsumen yang diwawancarai "harga disini murah, saya sudah berkali-kali beli tanaman hias disini, walaupun tidak jarang tanaman hias yang saya beli mati tapi saya selalu membeli lagi. Selain itu, penjual disini juga ramah dan pelayanannya juga baik" (hasil wawancara dengan konsumen 21 Februari 2020).

Dari hasil tersebut dapat disimpulkan bahwa penjual tanaman hias sudah membedakan harga berdasarkan segmen konsumen yang tepat, oleh karena itu para penjual sudah layak untuk menerapkan strategi diskriminasi harga.

\section{E. KESIMPULAN DAN SARAN}

Berdasarkan penelitian dan pembahasan pada bab sebelumnya, maka diperoleh beberapa kesimpulan sebagai berikut:

1. Alasan penjual tanaman hias menerapkan strategi diskriminasi harga adalah untuk mendapatkan keuntungan yang lebih dibandingkan hanya menerapkan harga dasar.

2. Para penjual tanaman hias menerapkan strategi diskriminasi harga yang dilakukan berdasarkan konsumen, dan kuantitas pembelian, maka dapat disimpulkan bahwa jenis diskriminasi harga yang sudah dilakukan para penjual tanaman hias yaitu:

a. Diskriminasi harga tingkat pertama, penjual menerapkan harga yang berbeda untuk masing-masing konsumen, dimana tidak didasarkan pada atribut konsumen, melainkan melalui pengenalan konsumen secara mendalam yang pada akhinya dapat menginterpretasikan kemampuan maksimum setiap individu konsumen untuk membayar.

b. Diskiriminasi harga tingkat kedua, penjual tanaman hias melakukan penyesuaian harga berdasarkan kuantitas pembelian konsumen, dimana semakin banyak kuantitas pembelian maka semakin besar kemungkinan untuk mendapatkan harga yang relatif murah, maupun mendapatkan bonus.

c. Diskriminsi harga tingkat ketiga, penjual tanaman hias menyesuaikan harga berdasarkan kelompok konsumen, yaitu kelompok konsumen peritel dan kelompok konsumen tamu.

3. Cara dan proses penjual dalam menerapkan strategi diskriminasi harga adalah:

a. Berdasarkan konsumen, yang pertama dilakukan memisahkan segmen konsumen, lalu melakukan pengenalan konsumen secara mendalam, selanjutnya komunikasi dan negosiasi berbeda antar konsumen yang dilayani, lalu menetapkan harga akhir.

b. Berdasarkan kuantitas pembelian, dengan melihat jumlah pembelian konsumen, lalu memberi harga yang standar, dan memberi bonus bila memungkinkan.

4. Penjual tanaman hias menerapkan strategi diskriminasi harga ketika terdapat konsumen yang dikenakan strategi diskriminasi harga, akan tetapi para penjual sepenuhnya memenuhi syarat untuk menerapkan strategi diskriminasi harga.

Berdasarkan kesimpulan tersebut, maka penulis memberikan rekomendasi kepada para penjual tanaman hias untuk lebih berhati-hati dalam menerapkan diskriminasi harga dan menjaga kerahasiaan diskriminasi pada konsumen-konsumen tertentu yang sensitif 
terhadap harga, karena apabila konsumen mengetahui mengenai kebijakan ini maka memungkinkan adanya asumsi yang buruk mengenai usaha tanaman hias penjual.

Selain itu, alangkah lebih baiknya apabila sudah terdapat patokan harga untuk setiap segmen konsumen, sehingga perbedaan harga hanya di lakukan berdasarkan pada kelompok segmen konsumen saja, bukan berdasarkan individu konsumen karena mengakibatkan surplus konsumen yang menurun dan mengakibatkan harga terlalu tinggi untuk beberapa orang.

Penelitian ini juga sudah sesuai dengan teori yang paparkan oleh Poort \& Borgesius (2019) mengenai tingkatan diskriminasi harga, Yelkur \& Nêveda Dacosta (2001) mengenai tahapan diskriminasi harga, Sugiarto (2016) mengenai syarat ditetapkannya diskriminasi harga dan sudah sejalan dengan penelitian sebelumnya yang dilakukan oleh Simshauser (2018) serta Luttmann (2019) mengenai tingkatatan diskriminasi yang diterapkan pada harga listrik dan maskapai penerbangan.

Penelitian ini memiliki keterbatasan dalam hal tingkat respon informan yang rendah sehingga cakupan informasi yang lebih luas sulit didapatkan, hal ini terjadi karena sulitnya pemahaman narasumber mengenai wawancara yang dilakukan. Oleh karena itu penelitian lanjutan masih diperlukan dengan melakukan wawancara menggunakan bahasa yang lebih dimengerti oleh narasumber dan menambah subjek yang lebih inti seperti pengurus kelompok tani tanaman hias, maupun petani tangan pertama sehingga diperoleh informasi yang lebih lengkap dan nyata mengenai diskriminasi harga yang diterapkan pada produk agrikultur khususnya tanaman hias.

\section{DAFTAR PUSTAKA}

Chang, X., Li, J., Rodriguez, D., \& Su, Q. (2016). Agent-based simulation of pricing strategy for agri-products considering customer preference. International Journal of Production Research, 54(13), 3777-3795. https://doi.org/10.1080/00207543.2015.1120901

FEDEP - Barenlitbangda Kabupaten Semarang. (2014). Retrieved October 7, 2019, from http://barenlitbangda.semarangkab.go.id/52-sentra-unggulan-binaan-fedep.html

Griffiths, A., \& Wall, S. (2005). Economics for Business \& Management: A Student Text.

Hupperich, T., Wilkop, N., Tatang, D., \& Holz, T. (2018). An empirical study on online price differentiation. CODASPY 2018 - Proceedings of the 8th ACM Conference on Data and Application Security and Privacy, 2018-Janua(March), 76-83. https://doi.org/10.1145/3176258.3176338

Hustic, I., \& Gregurec, I. (2015). The influence of price on customer's purchase decision. Central European Conference on Information and Intelligent Systems, 1-6.

Kencana, S. (2019). Analisis Strategi Penetapan Harga SKM.CLOTHING. 1003-1011.

Kotler, P., Keller, K., Brady, M., Goodman, M., \& Hansen, T. (2016). Marketing Management Fifteenth Edition. https://doi.org/10.1080/08911760903022556

Lesmana, R. (2015). analisis strategi pemasaran untuk meningkatkan penjualan perumahan green river city bekasi (study kasus di pt. artha bangun pratama) (Doctoral dissertation, Universitas Pamulang).

Luttmann, A. (2019). Evidence of directional price discrimination in the U.S. airline industry. International Journal of Industrial Organization, 62, 291-329. https://doi.org/10.1016/j.ijindorg.2018.03.013

Nagle, T. T., \& Muller, G. (2018). The Strategy and Tactics of Pricing ( A Guide to Growing More Profitably) (6th ed.).

Poort, J., \& Borgesius, F. J. Z. (2019). Does everyone have a price? Understanding people's attitude towards online and offline price discrimination. Internet Policy Review, 8(1). https://doi.org/10.14763/2019.1.1383

Ricard, G., \& Crichton, R. (2017). Munich Personal RePEc Archive As Seen on TV: Price 
Discrimination and Competition in Television Advertising As Seen on TV: Price Discrimination and Competition in Television Advertising. (75993).

Samosir, C. B. H., \& Prayoga, A. B. (2015). Jurnal Pengaruh Persepsi Harga Dan Promosi Terhadap Keputusan Pembelian Konsumen Produk Enervon-C. Jurnal IImiah Manajemen Dan Bisnis, 1(2), 1-13. https://doi.org/10.22441/jimb.v1i3.570

Saragih, H. (2015). Analisis strategi penetapan harga dan pengaruhnya terhadap volume penjualan pada pt. nutricia indonsesia sejahtera medan. 1(2), 46-54.

Satria, A. A. (2017). Pengaruh Harga, Promosi, dan Kualitas Produk Terhadap Minat Beli Konsumen Pada Perusahaan A-36. Jurnal Manajemen Dan Start-Up Bisnis, 2(April), $1-9$.

Sekaran, U., \& Bougie, R. (2016). Research Methods for Business. Encyclopedia of Quality of Life and Well-Being Research, 3336-3336. https://doi.org/10.1007/978-94-0070753-5_102084

Simshauser, $\bar{P}$. (2018). Price discrimination and the modes of failure in deregulated retail electricity markets. Energy Economics, 75, 54-70. https://doi.org/10.1016/j.eneco.2018.08.007

Sugiarto, I. (2016). Perspektif IImu Ekonomi Dan Undang-Undang Nomor 5 Tahun 1999 Tentang Larangan Praktik Monopoli Dan Persaingan Usaha Tidak Sehat Terhadap Diskriminasi Harga. Jurnal Wawasan Yuridika, 33(2), 153. https://doi.org/10.25072/jwy.v33i2.101

Sunardi, N., \& Lesmana, R. (2020). Pelaksanaan Alokasi Dana Desa Terhadap Manajemen Keuangan Desa dalam Meningkatkan Efektivitas Program Desa Sejahtera Mandiri Di Desa Cihambulu, Kec. Pabuaran, Kab. Subang. Jurnal SEKURITAS (Saham, Ekonomi, Keuangan dan Investasi), 3(3), 277-288.

Suhaily, L., \& Darmoyo, S. (2017). Effect of product quality, perceived price and brand image on purchase decision mediated by customer trust (study on japanese brand electronic product). Jurnal Manajemen, 21(2), 179-194. https://doi.org/10.24912/jm.v21i2.230

Sumarwan, U. (2013). Riset pemasaran dan konsumen. (3), 978-979.

Waldfogel, J. (2015). First Degree Price Discrimination Goes to School. Journal of Industrial Economics, 63(4), 569-597. https://doi.org/10.1111/joie.12085

Whitfield, R. I., \& Duffy, A. H. B. (2013). Extended revenue forecasting within a service industry. International Journal of Production Economics, 141(2), 505-518. https://doi.org/10.1016/j.ijpe.2011.11.015

Yelkur, R., \& Nêveda Dacosta, M. M. (2001). Differential pricing and segmentation on the Internet: The case of hotels. Management Decision, 39(4), 252-262. https://doi.org/10.1108/00251740110391411 